\title{
Exploration of "Tension" in Beloved from the Aspects of Theme, Characters and Aesthetics
}

\author{
$\mathrm{Xian} \mathrm{Wu}^{1}$ \\ ${ }^{1}$ Guangdong University of Science and Technology, Dongguan 523083, China \\ Correspondence: Xian Wu, Guangdong University of Science and Technology, Dongguan 523083, China. E-mail: \\ 876550713@qq.com
}

Received: September 14, 2020 Accepted: October 20, 2020 Online Published: November 13, 2020

doi:10.5539/ells.v10n4p34 URL: https://doi.org/10.5539/ells.v10n4p34

\begin{abstract}
Beloved written by Toni Morrison is brimming with profound sense and tension which have been focused on by an increasing large number of scholars at home and abroad. The word "Tension" means the balance between at least two inconsistent literary factors which cannot be dispelled by their opposed relationships. Based on the sense of tension and previous studies, this thesis is about further exploring its tension in themes, characters, and aesthetics. The author employs many kinds of rhetoric, such as symbol, simile, personification and poetization, representing a new method of rhetoric and contributing to a unique "black" poetic impression, which makes the story not only have the charm of form, but the tension of its idea and spirit of nationality.
\end{abstract}

Keywords: Beloved, tension in themes, tension in characters, tension in aesthetics

\section{Introduction}

The word "tension" is first applied in physics. It is a kind of interior attractive effort between two opposite forces. While with the fast development of interdisciplinary, it has been first put forward by Allen Tate in his work On the Tension in Poetry in 1937. He says, "I put forwards the word of tension, having no intention of applying it as an ordinary technique of simile, but as a specific noun. It is formed by abandoning the prefix of its denotation and connotation of the logical terms, that is to say, a kind of organic system including its denotation and connotation." From then on, the word tension has been used in poetry and gradually gotten its literary concept, meaning the balance between at least two inconsistent literary factors which cannot be dispelled by their opposed relationships. These kinds of contrary states, being against each other, offer the readers a modeling effect under the influence of multiple thoughts.

According to this explanation, the tension is a new ordered state formed by those disharmonious and opposing factors and tendencies. And now the word "tension" has been widely used in literature of all aspects, making poem, prose, fiction and drama much more profound and thought-provoking. The famous long story Beloved is a good interpretation of it. The story is mainly about how and why a black woman kills her own daughter named Beloved who haunts and affects her life and spirit later. Under the influence, her memory about the past is gradually discovered with the passage and changes of time, representing us a deep understanding of the tragedy about the black people and a new sight of the complicated humanity. To create this mysterious and fantastic atmosphere, the author has employed the method of tension between the time and the space, and the real scenes. And then the following part will discuss the tension in themes, characters, and aesthetics in details.

\section{The Tension in Themes}

The themes in the long story Beloved are multilevel. On the one hand, it presents a magic realism of literature, obscuring the boundary between the fantasy and the reality. On the other hand, it reveals the inequality between the white and the black, which leads those black people escaping from their life and fighting for their freedom. At the same time, it embodies how great and unique maternal love is. Thus, the tension in the themes can be shown from three aspects: the reality versus the fantasy, the white nationality versus the black ethnicity, the unusual affection versus the ordinary love. These contradictory relationships come to a certain kind of balance under the influence of tension, offering the readers a new sight to appreciate literature and improving the sense of beauty in art. 


\subsection{The Reality Versus the Fantasy}

The story is adapted from a real event which narrates the experience of a black woman happened in Ohio. Therefore, it is easy for us to connect it with the reality, especially those people in the long story depicted by the author are so vivid and authentic, making us hardly aware of its fictionality. Meanwhile, with the emergence of the magical and fantastic factors in the long story, such as the so-called ghost Beloved appearing in the house and her strange behavior, the boundary between the fantasy and reality becomes vague and indistinct. The girl really existing or not adds the sense of magic and mystery, not only confusing the readers, but also puzzling the heroine Sethe. Obviously, the tension between the reality and fantasy occurs at the same time.

The heroine Sethe gradually lost her realization of time and confused her past and the present. The memory of her experience did great harm to her physically and psychologically. Especially with the coming of the girl Beloved, Sethe took her for her dead daughter whom she had killed. Sethe devoted herself to taking good care of the ghost. They live and play, which obscured the real and the ideal. Clearly, the tension between them came to its climax at the same time, offering readers a complicated emotions and understandings of their identity. It is deeply inconceivable that a ghost can live with people so easily and vividly, creating a seemingly mysterious and real atmosphere.

The author arranges a series of scenes to reveal her inner thoughts and love, building a sense of indistinction and leading to some incredible and misty notions in the readers' mind: Is it true or not? While with the development of plot, the boundary between the reality and the fantasy does not matter at all; they are the same to some extent. The tension comes to its balance in the end, giving rise to a thought-provoking argument.

\subsection{The White Nationality Versus the Black Ethnicity}

At that time, the slavery was prevailed and popular. The black people lived in hard and miserable conditions, without freedom and equality, and they were at the mercy of the white. Being oppressed, exploited, and enslaved, they almost had no choice but to surrender and take their fate down. With the development of society, fortunately, their consciousness gradually awakened instead of reducing into total numb. They realized that they must fight against the cruelty and the inequality. The conflicts between the black and the white broke out; actions would be taken sooner or later.

Those black people in the story, such as Sethe, Paul D, Halle, and Sixo, tried to escape from their tragic life and made plans about how to run away. But their power seemed to be so feeble, difficult to get rid of the cruelty and inhumanity of their master Schoolteacher and Sawyer who was the owner of the restaurant where Sethe worked. Taking the following as example,

Rain the mother's milk, they had already done. Driven her fat bellied into the woods - they had not that. All news of them was not. They buttered Halle's face; gave Paul D iron to eat; crisped Sixo; hang her own mother. She didn't want any more news about white folks. (188: Toni Morrison)

Their miserable past life was totally unbearable. Sethe did not want to remember what they had suffered and her own painful slavery in the past.

It is admitted that the black suffered a lot. While not all the white were the controllers and rulers, some of whom were also the victims, such as Mr. Garner, Amy and Sawyer. Mr. Garner was the first owner of the Sweet Home. He treated the slaves as humans and encouraged them to be independent, decisive, and defiant. He was a master who lived harmoniously with the slaves. Amy was the girl who saved Sethe when she ran away from Sweet Home. She represented a group of oppressed white people in the slavery. Sawyer is also the victim of the slavery system. At first, he was very gentle, but later he changed because of the death of his son. The real factor changed his temper was the slavery system, such as the author read,

That for every school-teacher there must would be an Amy; that for every pupil there was a Garner, or Bodwin, or even a sheriff, whose touch at her elbow was gentle and who looked when was nursed. (200: Toni Morrison)

Those white people's experience reveals two sides of white human. Thus, there is no definite division between the white and the black, just as there is no absolute virtue and vice. This kind of melting ambiguity contributes to the occurrence of tension between them, reaching the unity of opposites, which adds its readability and arises more interpretations of those characters and its ideas in the long story.

\subsection{The Abnormal Affection Versus the Ordinary Love}

The heroine in the story presents a great and common femininity. Although she is black, she has the courage to seek freedom and happiness. When the white exerts huge oppression on her, she struggles to run away from 
violence and exploitation. During the process of her strenuous escape, she makes up her mind to kill her daughter to protect her from suffering what she has experienced. Maybe someone does not quite understand her behavior, and accuses her of madness, but at that time she has no choice. Who can exactly know her hard struggle and hopeless heart under that circumstance? Her love has surpassed every worldly love, especially when the girl Beloved stepping into her life. She takes it for her own daughter and her behavior shows us how great and unusual the maternal love is. We can see it from the following paragraphs:

Beloved, she is mine daughter. She mine. See. She comes back to me of her own free will and I don't have to explain a thing. I didn't have time to explain before because it had to be done quickly. (237: Toni Morrison)

Sethe believes that Beloved is her murdered daughter who has come back. Since then she could not concentrate on her work except that she, Denver and Beloved, they three devoted themselves to playing games cooking, sewing, and the hair and dressing games. No matter what Beloved asked, Sethe would satisfy herself, even some questions and events that she knew. Beloved gradually called up her privately shameful things, as followings read,

Sethe learned the profound satisfaction Beloved got from storytelling. It amazed Sethe (as it pleased Beloved) because every motion of her past life hurt. Everything in it was painful or lost... Perhaps is was Beloved's distance from the events itself, or her thirst for hearing it - in any case, it was an unexpected pleasure. (69: Toni Morrison)

The past and the present are mixed in Sethe's mind, which leads to some kind of confusion in her. But she is sure that Beloved is her daughter. She manages to find reason for whatever she had done to her daughter in the past, as the novel says,

I got down on her knees to beg God's pardon. My plan was to take us all to the other side. They stopped me from getting us there, but they did not stop you from getting here. Ha ha, you came right on back like a good girl, like a daughter..." (87: Toni Morrison)

Her love to Beloved is not like any worldly love, but a certain sort of insane affection. She indulges herself in keeping company with Beloved and taking care of her heart and soul. This kind of abnormal affection not only presents the great maternal love, but forms a striking contrast with the ordinary love, thus the tension between them occurring, arousing much more sympathies and reflection in the readers' mind.

\section{The Tension in Characters}

A character cannot exist in isolation, no matter in novels or reality. Everyone is a part of the world, and is closely related with each other. So, the relationships of characters can be explained in two aspects: individuality and community, and true self and false self.

\subsection{The Individuality Versus the Community}

After the emancipation from slavery, Sethe chose to live with her daughter Denver alone in the Sweet Home, far away from those people in the town. She decided to forget what she had suffered, seldom talking with others, even with Denver and Paul D, and losing herself in her own world.

With the coming of the ghost Beloved, who would take revenge on her, she gradually lost her mind. She took Beloved for her daughter and did everything for her, which made Beloved greedy and stronger. What's worse, Beloved took all kinds of actions to control Sethe and to keep her as her own mother and possess her maternal love. For instance, she had sex with Paul D to drive him away and pushed Denver aside in the Sweet House. Gradually, Sethe became weaker and weaker, and almost came near to death. Because of the haunted house, others did not dare to come close to the house. It was Denver who sought help from her neighbors Lady Jones, M. Lucille Williams, Ella, and Bodwins for saving her mother Sethe out of Beloved's hands. Undoubtedly, it showed the importance of community. With her neighbors' assistance, Sethe was back again to her life and the ghost Beloved went away in the end.

It is the union with the community that saves Sethe. The tension between the individuality and the community occurs when Sethe comes back to the group. As a matter of fact, everyone is connected with each other to some extent in the society. Leaving away from others can not be an effective way to realize oneself, since every human's power is limited. Only being in harmony with the group or community can we make great progress in improving ourselves and saving us from some dangerous situations.

\subsection{The True Self Versus the False Self}

Living in that period filled with conflicts and discrimination between the white and the black, it is difficult for 
the black to be themselves, thus their identities are ambiguous, and they nearly do not know who they are. Judging from their names, we can see the tension between true self and false self, that is to say, what they really are and where they belong, such as Baby Suggs, Beloved, Paul A, Paul D, and other slaves.

The name Baby is how her husband called her and Suggs is her husband's name. Baby Suggs knows nothing about herself, not even what she looks like. She has no "self", "Sad as it was that she did not know where her children were buried or what they looked like if alive, fact was she knew more about them than she knew about herself, having never had the map to discover what she was like" (53: Toni Morrison). She hardly realized her existence in the world, totally losing herself.

Beloved is a single word on her tombstone and from the love her mother bears her. "Ten minutes for seven letters. With another ten could she have gotten "Dearly" too... she could have had the whole thing every word she heard the preacher say at the funeral engraved on her baby's headstone: Dearly Beloved" (5: Toni Morrison). Beloved has no identity other than merged with the "sixty million and more" of the dedication.

The slaves' names are randomly called by their masters, like Paul A and Paul D. Their names, bearing no meaning at all, only serve as labels for their owners. These slaves have no choice to name themselves, unaware of who they are. Just as in context, when mentioning them, "One crazy. One sold. One missing, one burnt and me licking iron with my hands crossed behind me" (72: Toni Morrison).

From the above analysis, the existence of the slaves is easily ignored by the contemporary people, but it can not be forgotten by the readers because of its emotional resonance. That they are real or not shows the tension and ambiguity of characterization in the novel, adding the depth and sense of it.

\section{The Tension in Aesthetics}

Aesthetics is a branch of philosophy concerned with the study of the idea of beauty, emphasizing the evaluative criteria that are applied to art. To be more concrete, the idea of beauty in literature can be manifested in language, images, symbols, and rhetorical devices. The novel has justly represented the aesthetics in two sides based on the above factors: the dynamic conditions and the static states, and the external senses and the internal references.

\subsection{The Dynamic Conditions Versus the Static States}

With the change of scenes and time, the environment in the story plays an important role in contributing to a proper state of the characters' mind. The tension between them comes to the climax. For example,

It was nearly four o'clock now and 124 was half a mile ahead. Floating toward them, barely visible in the drifting snow, was a figure, and although it was the same figure that had been meeting Sethe for four months... Saying, "You got to learn more sense than that," she enclosed her in her left arm. Snowflakes stuck now. Paul D felt icy cold in the place Sethe had been before Beloved came. (153: Toni Morrison)

Stretched out to his full length, watching snowflakes stream past the window over his feet, it was easy to dismiss the doubts that took to the alley behind the restaurant: his expectations for himself were high, too high. (155: Toni Morrison)

The above paragraphs describe the scene of snowflakes, showing the change of Paul D's mood. At first, it was drifting snow when Sethe and Paul D were having fun and Beloved was coming. They were shocked, stirring up a certain kind of roaring emotions for Paul D. And then, when Sehte took the shawl and wrapped it around Beloved's head and shoulders and enclosed her in her left arm, snowflakes stuck. It seemed everything was motionless in Paul D's eyes, revealing his unspeakable state of mind. He realized Sethe's love for Beloved was beyond everything at that time. Later, when Sethe came back, he saw snowflakes streaming down the window, reminding him of the reality, which showed his hard struggle and sorrow in his heart.

\subsection{The External Senses Versus the Internal References}

The meanings of some words and objects are various and rich in the story, so the tension between the external senses and the internal references appears accordingly, such as Sethe's back wound as the image of a tree, Sweet Home as a horrible haunted house, the water (sea and Ohio River) as a disaster and freedom.

Firstly, it is the tree on Sethe's back. At the beginning of Beloved, the text reads, "Sethe's back skin had been dead for years" (18: Toni Morrison), as a result of savage beating and it is incapable of feeling. For Sethe, these scars constitute "traces of past deeds too horrible and violent either to forget or to remember, a situation that Morrison describes elsewhere as a perfect dilemma" (Mae G. Henderson, 87).

In the eyes of Amy who helped Sethe when she ran away, the scars as a tree present a faith and a hope. Taking the following as examples, 
It's a tree, Lu. A chokecherry tree. See, here's the trunk-it's red and split wide oped, full of sap, and this here's the parting for the branches. You got a mighty lot of branches. Leaves, too, look like, and dern if these ain't blossoms. Tiny little cherry blossoms, just as white. Your back got a whole tree on it. In bloom. (93: Toni Morrison)

As a victim of the white people, she bears an optimistic attitude towards life rather than reducing into desperation, which is typical of American characters who are independent, positve and pride. She considers the tree as her positive hope, believing that the chokecherry tree will in bloom.

As for Baby Suggs, Sethe's "flowering back" is a pattern of "rose of blood" She does not speak of the wounds, but "hide her mouth with her hand...wordlessly the older woman greased the flowering back and pinned a double thickness of cloth to the inside of the newly stitched dress" (93: Toni Morrison). Baby Suggs thinks that black women have no voice but to bear what they have suffered.

Secondly, the so-called Sweet Home is not warm and sweet at all. It is the place where imprisons the freedom and thoughts of the black people. Something evil and violent always happens in the house, which is totally beyond people's imagination. As the text reads, “How come everybody run off from Sweet Home can't stop talking about it? Look like if it was so sweet you would have stayed.' Paul D laughed. 'True, true. She's right, Sethe. It wasn't sweet and it sure wasn't home.' He shook his head." (98: Toni Morrison). It sounds to be so ironic, but it is the fact. Sweet Home, a place with beautiful landscape and a sweet name, is somewhat a paradise or, a "Garden of Eden" in the initial period. But all the seemingly fairy-tale life comes to an end when Schoolteacher arrives.

Thirdly, the water can represent the disaster for the slaves; it can also stand for the freedom of them. In the novel, Baby Suggs is the typical and tragical character, totally tortured by her memory of the past, as the context reads,

She told Sehte that her mother and Nan were together from the sea. Both were taken up many times by the crew. She threw them all away on the island. The ithers from more whites she also threw away. Without names, she threw them. You she gave the name of the blackman. (64: Toni Morrison)

Baby Suggs looks back, scenes of the past on the sea leapt before her eyes. Here the sea is an evil force and a ghost, torturing black salves' mentality, their nature and destiny, destroying their hope and life.

On the other hand, the Ohio River serves a means of escaping and releasing. Under the oppression of the white slave-owners, those black slaves all desire to break the bounds of the slavery, going to the Ohio River where they can run off from their miserable life and gain their freedom. With the awareness of what they really are, the black slaves decide to go into exile, and it happens on the Ohio River.

From the above analysis, the images of tree, Sweet Home and the water give a vivid description of black slaves' life. What is more, the tension between the external senses and the internal references creates a stereoscopic sense, adding the appreciation of beauty and the aesthetic value. It gives readers a new sight to review the objective things of the outwards and its containing meanings in an overall angle.

\section{Conclusion}

The novel Beloved, which is mainly about how and why a black woman kills her own daughter named Beloved who haunts and affects her life and spirit later, is turned out to be filled with tension. After analyzing the tension in themes, characters, and aesthetics, we may further discover that the beauty of tension is not born in harmony and it is achieved when, at least, two opposite elements reach into a balance after a process of counterwork. In other words, this kind of balance or harmony is based on the two opposite elements' conflict, such as fantasy and reality, individuality and community, static and dynamic and so on in this novel.

Apparently, the tension possesses a special kind of beauty. It deepens and enriches the senses and meanings of the story, adding the value of aesthetics. Its profound ideas, symbolic images, daunting metaphors, and powerful language are all represented vividly in the story. It is the superficial disharmony of opposite partners and the multiple meanings that lead to some obstacles for readers to appreciate the story and thus it prolongs the course of readers' interpretation.

Above all, the tension cannot be ignored in this piece of magical-realism and ironic story, for its plentiful contradictions make it more ambiguous and mysterious, unveiling another creative way of writing. As for readers, more attention, imagination, and intelligence will be involved in this process so that they can get a deeper understanding of the novel. Undoubtedly, the tension has been playing an increasingly more important and indispensable role in literature and art with the passage of time. 


\section{References}

Allen, T. (1937). On the Tension in Poetry. Princeton University Press.

Chang, Y. X. (2008). USA History in Brief. Tianjing: Nankai University Press.

Mae, G. H. (2003). Josephine Baker and La Revue Negre: from ethnography to performance. Text and Performance Quarterly, 23(2). https://doi.org/10.1080/1046293032000141338

Spencer, S. (1971). Space, Time and structure in the Modern Novel. New York: New York University Press.

Sun, S. (2007). On the Synopsis of Tension. Shandong: Shandong University Press.

Toni, M. (1997). Beloved. Beijing: Foreign Language Press.

Wang, Y. C. (1994). Aesthetic Methodology of Literature and Art. Beijing: Peking University Press.

Wilfred, L. G., Earle, L., Lee, M., Jeanne, C. R., \& John, R. W. (2004). Oxford. Lundon: Oxford University Press.

\section{Copyrights}

Copyright for this article is retained by the author, with first publication rights granted to the journal.

This is an open-access article distributed under the terms and conditions of the Creative Commons Attribution license (http://creativecommons.org/licenses/by/4.0/). 